\title{
Cybersecurity and Custom Regulations as Trade Barriers in ASEAN e-Commerce: Case of Indonesian e-Commerce
}

\author{
Annisa Pratamasari \\ Universitas Airlangga
}

\begin{abstract}
ASEAN countries show tremendous potential for e-commerce growth. Boasting its 650 million population and massive internet users, ASEAN proves to be a significant market for e-commerce and digital economy in general. Nonetheless, there are still some significant barriers in e-commerce trade, both traditional and non-traditional barriers of trade. Those barriers include a lack of harmonized regulations between the ASEAN Member States, high tariff duties on imported goods and weak consumer protections (and overall cybersecurity) in the region. This study explores these barriers, which hinder ASEAN's goal to achieve more robust growth in the digital economy, particularly in terms of legal framework (custom harmonization) and cybersecurity. In order to delve more deeply into these impediments of e-commerce trade, this article also attempts to present a case study of Indonesia's e-commerce as the most prominent and most promising player in ASEAN.
\end{abstract}

Keywords: ASEAN, e-commerce, digital trade, digital economy

Negara-negara ASEAN menunjukkan potensi luar biasa bagi pertumbuhan e-commerce. Dengan jumlah penduduk 650 juta dan banyaknya pengguna internet, ASEAN terbukti menjadi pasar yang signifikan bagi e-commerce dan ekonomi digital secara umum. Meskipun demikian, masih terdapat beberapa hambatan signifikan dalam perdagangan e-commerce, baik hambatan perdagangan tradisional maupun non-tradisional. Hambatan-hambatan itu termasuk kurangnya regulasi yang harmonis antara negara-negara anggota ASEAN, bea masuk yang tinggi untuk barang-barang impor, dan lemahnya perlindungan konsumen (serta keamanan cyber secara keseluruhan) di dalam kawasan. Penelitian ini mengeksplorasi hambatan-hambatan yang menghambat tujuan ASEAN untuk mencapai pertumbuhan yang lebih kuat dalam ekonomi digital, terutama dalam hal kerangka hukum (harmonisasi aturan) dan keamanan cyber. Untuk menggali lebih dalam hambatan-hambatan perdagangan e-commerce ini, tulisan ini juga mencoba untuk menyajikan studi kasus e-commerce Indonesia sebagai pemain terbesar dan paling menjanjikan di ASEAN.

Kata-kata kunci: ASEAN, e-commerce, perdagangan digital, ekonomi digital 
Association of Southeast Asian Nations (ASEAN) celebrated its 50 ${ }^{\text {th }}$ anniversary in 2017 and has emerged as one of the most promising regional organizations. ASEAN Member States (AMS) agreed to accelerate the process toward further economic integration under the ASEAN Economic Community (AEC), particularly in trade liberalization. Similar to European Union (EU) and most regional organizations, ASEAN and AEC are parts of political projects among nation-states aiming to foster a relationship between themselves by liberalizing movement of factor productions (goods, services, labors and investment). In order to grow and foster a partnership with other economies, ASEAN mostly boasts its vast market, which accounted for more than 622 million people, and its cumulated GDP is around USD 2.5 trillion (ASEAN Secretariat 2017).

Widening the organization, AMS first discussed e-commerce agreement in June 2017, finished it in nine rounds of negotiations, and signed it on the 33rd ASEAN Summit and Related Meetings in November 2018 (Singapore Government 2018). Following up on the agreement, AMS identifies some work programs to facilitate e-commerce growth within the region, including infrastructure, education and technology competency, consumer protection, modernization of legal framework, transaction security, competition, logistics, and framework (ASEAN 2019). ASEAN's e-commerce development is still in the early state, yet seeing the landscape in Table 1 below, it signals a promising future.

Table 1. ASEAN e-Commerce Landscape

\begin{tabular}{lrrrrrrr}
\hline & $\begin{array}{c}\text { Total } \\
\text { Population }\end{array}$ & \multicolumn{1}{c}{$\begin{array}{c}\text { Internet } \\
\text { users }\end{array}$} & $\begin{array}{c}\text { Internet } \\
\text { penetration }\end{array}$ & $\begin{array}{c}\text { Mobile } \\
\text { connections }\end{array}$ & $\begin{array}{c}\text { Mobile } \\
\text { penetration }\end{array}$ & $\begin{array}{c}\text { GDP per } \\
\text { capita }\end{array}$ & $\begin{array}{c}\text { Mediau } \\
\text { age }\end{array}$ \\
\hline Brunei & $0.43 \mathrm{~m}$ & $0.4 \mathrm{~m}$ & $95 \%$ & $0.53 \mathrm{~m}$ & $124 \%$ & US $\$ 77,571$ & 31 \\
Cambodia & $16.13 \mathrm{~m}$ & $8.00 \mathrm{~m}$ & $50 \%$ & $29.20 \mathrm{~m}$ & $181 \%$ & US $\$ 3,744$ & 2 \\
Indonesia & $265.40 \mathrm{~m}$ & $132.70 \mathrm{~m}$ & $50 \%$ & $177.90 \mathrm{~m}$ & $67 \%$ & US $\$ 11,632$ & 31 \\
Lao PDR & $6.9 \mathrm{~m}$ & $2.40 \mathrm{~m}$ & $35 \%$ & $6.30 \mathrm{~m}$ & $91 \%$ & US $\$ 6,196$ & 2 \\
Malaysia & $31.83 \mathrm{~m}$ & $25.08 \mathrm{~m}$ & $79 \%$ & $21.62 \mathrm{~m}$ & $68 \%$ & US $\$ 27,736$ & 2 \\
Myanmar & $53.6 \mathrm{~m}$ & $18.00 \mathrm{~m}$ & $34 \%$ & $53.98 \mathrm{~m}$ & $101 \%$ & US $\$ 5,732$ & 2 \\
Philippines & $105.70 \mathrm{~m}$ & $67.00 \mathrm{~m}$ & $63 \%$ & $61.00 \mathrm{~m}$ & $58 \%$ & US $\$ 7,819$ & 2 \\
Singapore & $5.75 \mathrm{~m}$ & $4.83 \mathrm{~m}$ & $84 \%$ & $4.7 \mathrm{~m}$ & $82 \%$ & US $\$ 88,003$ & 3. \\
Thailand & $69.1 \mathrm{~m}$ & $57.00 \mathrm{~m}$ & $82 \%$ & $55.56 \mathrm{~m}$ & $80 \%$ & $\mathrm{US} \$ 16,946$ & 3 \\
Vietnam & $96.02 \mathrm{~m}$ & $64.00 \mathrm{~m}$ & $67 \%$ & $70.03 \mathrm{~m}$ & $73 \%$ & $\mathrm{US} \$ 6,435$ & 3 \\
TOTAL & $650.89 \mathrm{~m}$ & $379.42 \mathrm{~m}$ & $58 \%$ & $480.83 \mathrm{~m}$ & $74 \%$ & US $\$ 4,308$ & 29. \\
\hline
\end{tabular}

Source: Compiled by the presentor based on ASEAN-UP's posts. *The median age of ASEAN countries is from the KPMG report.

Source: Wei and Pratamasari (2019)

Based on the table above, ASEAN has a promising market of 650 million people, the internet has penetrated more than half of the region, and more than half of the population are already internet users. As apparent from Table 1 as well, mobile penetration among the ASEAN population reaches $74 \%$, with Indonesia has the largest population of mobile users. In contrast, countries with a smaller population like Myanmar, Brunei, and Cambodia have a more extensive mobile penetration than their actual population, indicating a tremendously high level of mobile penetration in their respective countries. Moreover, AMS also records relatively moderate to high GDP per capita (Singapore is the only developed country), and the average age of the population is less than 30 years old, which is the perfect age group as e-commerce's target market. 
Figure 1 below further highlights the immense potential growth of the e-commerce sector, which is projected to jump from USD 23 billion in 2018 to USD 102 billion in 2025. Compared to other sectors of internet economy like ride-hailing (and food delivery), online media (digital streaming and subscription), and online travel (flight ticketing and hotel booking), e-commerce has the largest projected growth of more than $50 \%$. All these statistical data indicate that ASEAN has a promising potential to grow in the future. Moreover, ASEAN is also home for several startup companies with a valuation of more than USD 1 billion in the digital economy, also known as unicorns. For example, Grab (a ride-hailing service company which is already a decacorn as its valuation has reached more than USD 10 billion); Gojek (ride-hailing and food delivery service); Lazada (B2B/B2C e-commerce); Tokopedia (B2C/C2C e-commerce); and Sea (a gaming company) (Varma and Boulton 2019). In total, the projected growth of ridehailing, subscription service, online travel, and e-commerce will reach USD 240 billion in 2025, jumping from the current valuation of USD 72 billion.

\section{Figure 1. Potential Growth of Internet Economy in ASEAN}

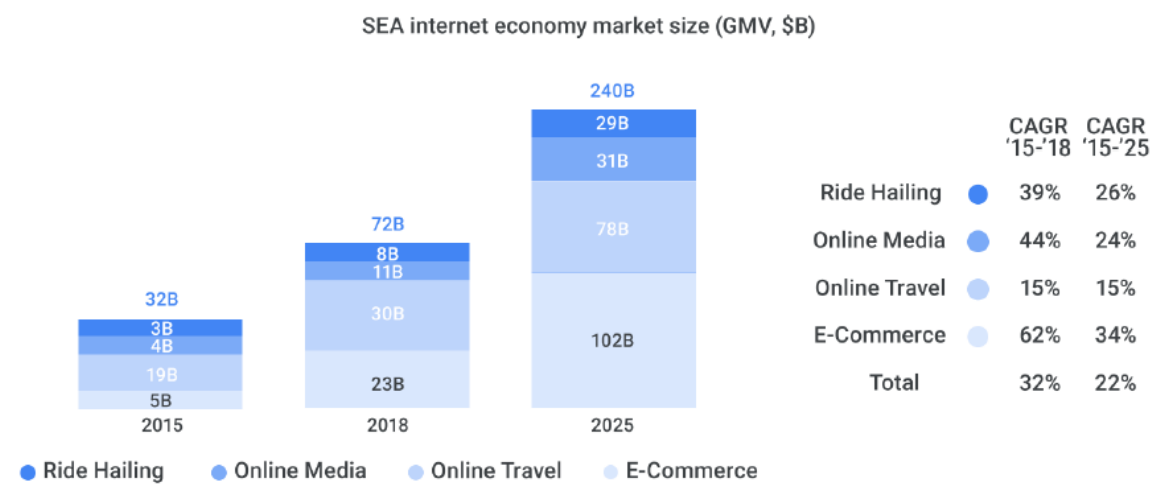

Source: Anandan et al. (2018)

Nonetheless, ASEAN also realizes some potential barriers in e-commerce trade, which might impede the current and potential growth in the future. As previously mentioned in its follow-up working program after its e-commerce agreement, there are some areas it should work on, namely infrastructure, competency, logistics, and legal regulations (including custom harmonization and cybersecurity). Therefore, this paper would like to explore these new challenges, which potentially act as the new barriers of trade, particularly in terms of the legal framework (custom regulations) and cybersecurity (including consumer protection). UNCTAD (UNCTAD-ASEAN 2013) also acknowledged that the enactment and enforcement of relevant legislation to real size the in a way that promotes regional integration are necessary measures in order to unleash the full potential of ASEAN's e-commerce. Moreover, to delve more deeply into these impediments of e-commerce trade, this article also attempts to present a study case of Indonesia's e-commerce.

\section{New Barriers of Trade and Impacts on ASEAN e-Commerce}

Challenges and obstacles in ASEAN e-commerce have also been noted by the Competition and Consumer Commission of Singapore, as presented in Table 2 below (Anandan et al. 2008). In terms of technological infrastructure, some AMS still need 
to improve their internet speed, internet services, and logistic issues. There are some differences in internet costs (affordability) and accessibility among countries, or even between provinces within a country. Overall, the digital divide among AMS is notably sizeable, with only Singapore made it to the TOP 10 list of countries with excellent ICT performance (AT Kearney 2015). In the case of Indonesia, there are even some regions where internet accessibility is extremely low. E-commerce is heavily reliant on the internet connection, so these factors can severely impact its growth. Moreover, since two of AMS are archipelago countries (the Philippines and Indonesia), it also brings about challenges in delivery service and logistics. For Indonesia, among 17,000 islands, it only has a handful of ports to handle international delivery, and the delivery service for the remote areas is negligible (OECD 2012).

Table 2. Main Impediments of ASEAN's e-Commerce Growth

\section{- Main impediments of ASEAN's E-Economic Growth}

\begin{tabular}{|c|c|c|}
\hline & $\begin{array}{l}\text { Expected annual growth } \\
\text { rate } 2017-2021(\%)\end{array}$ & Main impediments \\
\hline Indonesia & 20.1 & Cyber-security, product reliability \\
\hline Malaysia & 23.2 & Cyber security ,consumers preference for brick-and-mortar shoppin \\
\hline Philippines & 17.3 & Credit card penetration \\
\hline Singapore & 11.2 & Brick-and-mortar shopping culture \\
\hline Thailand & 15.9 & Cyber security, poor logistics, infrastructure \\
\hline Vietnam & 16.5 & Product reliability, cyber security, poor logistics \\
\hline Brunei & - & limited to the accommodation and transport booking sectors \\
\hline Lao PDR & - & $\begin{array}{l}\text { lack of investment in telecommunications infrastructure, } \\
\text { and the low rate of formal banking and credit card }\end{array}$ \\
\hline Cambodia & - & $\begin{array}{l}\text { inadequate infrastructure and low levels of credit } \\
\text { card penetration. }\end{array}$ \\
\hline Myanmar & - & $\begin{array}{l}\text { Internet access has, however, historically been unreliable } \\
\text { and slow. }\end{array}$ \\
\hline
\end{tabular}

Source: CCCS (2017), as compiled by the author

Another challenge is related to customer culture in ASEAN in which customers prefer brick-and-mortar shopping because they generally have low trust in online shops and e-commerce (AT Kearney 2015) and perceive that ASEAN e-commerce has low product reliability. A low level of trust is also related to data theft and fraud frequently occurred in ASEAN. As a result, cash on delivery (COD) option is widely preferred by the consumers because it is perceived to be safer than using banking or other electronic payment methods (Wei and Pratamasari 2019). This fact is validated by generally low credit card penetration in this region.

Those trends which hinder e-commerce growth are aggravated by the fact that ASEAN countries, respectively, have weak regulations against cybercrimes and even highly susceptible to cyberattacks (CCCS 2017). Another serious issue related to legality is custom regulations and cybersecurity, which shall be deeply explored in the subsequent sub-sections. AT Kearney's report also argued that a lag in establishing correct regulations (encompassing digital signature, privacy, data protection, financial services, etc.) and policy harmonization among ASEAN countries could hinder the potential growth of this sector in the future (AT Kearney 2015). 
Concerning international trade regulation, the conduct of international trade is generally regulated under the WTO framework, and it is supposed to include this new kind of trade, as well. The attempt to regulate digital trade started at the Second Ministerial Conference in 1998 under the "Declaration on Global Electronic Commerce" (Gao 2018); however, the attempt stopped there as the organization has made no further efforts in this area. As a result, regulations related to digital trade are mostly composed within bilateral or regional agreements, though it may cause a possible contradiction with WTO rules and create new barriers in trade in general.

The grey area in digital trade encompasses classification of goods or service which fall under 'digital goods/service', taxation and custom duties issues which affect tariff imposition on digital products, and cybersecurity-related issues (Ahmed and Aldonas 2015). Even though WTO generally delegates policy formulation to regional forums, it is still hard to reach a definitive agreement on these issues. It is even more so for ASEAN, which has less harmonized regulations compared to the EU, for instance (AT Kearney 2015). Compared to the EU, which placed common privacy initiative and data protection, some AMS have not yet its privacy law in place and have no common regulation. Cybersecurity also has not received significant priority in the ASEAN Master Plan, although AMS is aware of its importance. Custom regulations and cybersecurity are the main focus of this study. The existence of legal regulation is arguably essential to ensure the ease of e-commerce growth and operation, while the high level of cybersecurity can ensure the safety of both producers and consumers in e-commerce trade. In order to foster the growth of digital trade, this paper argues that a set of regulations shall be put in place as a critical element.

\section{Attempt to Harmonize Custom Regulation: ASEAN Single Windows}

ASEAN has not reached the level of economic integration that the European Union has and has not even formulated a common external tariff yet. As a result, each AMS has its regulation on taxation and custom, and it raises uncertainty in business. Most business people and customers are reluctant to purchase goods from overseas, as they either have no awareness or are extremely uncertain of custom rules, including the number of duties and length of handling. According to World Economic Forum, AMS recorded less efficient custom procedures (less than 4/5 out of 7 indexes), and only Singapore recorded a satisfying score (more than 6 out of 7) (World Economic Forum 2019). An ISEAS (2017) research summarized that custom clearance was the most demanded ASEAN trade facilitation measured in several surveys with more than 50\% of respondents from Japan, the US, and the EU. 
Figure 2. Custom Values of USD 100 Dress among AMS

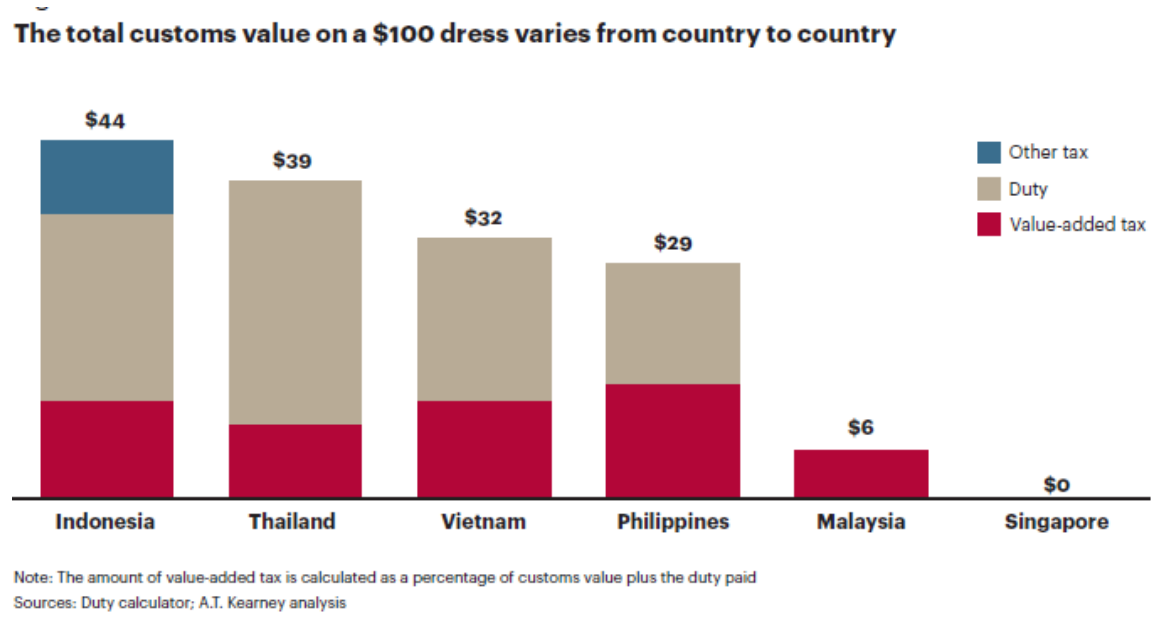

Source: AT Kearney (2015)

Based on the figure above, it shows that AMS has no synchronized policy on custom duties and consumers even end up losing as they have to pay more for USD 100 duties and taxes in Indonesia, Thailand, Vietnam, and Philippines. In Indonesia, the customers have to pay additional taxes on top of duties and value-added tax. AT Kearney (2015) further noted that Indonesia has the highest import rate for manufactured goods and adds more uncertainties compared to other AMS. AMS still regards that custom is the most crucial post to manage their borders; hence, the member countries still retain their duties and specific regulations on the inspection and handling. Adding to this lengthy and complicated procedure, most consumers in ASEAN (particularly Indonesians) have to pay more for imported goods, making them lose the full benefits of international trade and e-commerce in particular.

Aware of this barrier, ASEAN Single Window (ASW) was enacted as one of ASEAN's attempts to harmonize and simplify its custom regulations (ASEAN 2006). ASW encompasses custom procedures, documents, duties, and licenses for traded goods across ASEAN borders. It aims to facilitate trades and simplify all businesses related to custom in one single website where businesspeople (and the public in general) can access information regarding custom procedures and download the documents in one place. Likewise, custom officers can access certificates or licensed owned by corporations or business entities on the websites. By implementing ASW, it is expected that time spent for custom inspection will be shortened and in turn, it should reduce cost in business transactions (Gnanasagaran 2018). Nonetheless, the members may also have different institutions to oversee all procedures, though the Ministry of Finance in each member country generally oversees all custom-related activities (United Nations ESCAP 2015).

In its conceptual model, ASW involves 10 National Single Windows (NSW) and their respective customs, other government agencies (OGAs), banking and insurance agency, transport community, trading community, and ASEAN/ international link. Each agency in the scheme has its respective role (ASEAN 2006). Custom declares duty, OGAs approves permits, banks proceeds payment, transport community provides manifest and vessel information, and trading community prepares 
commercial documents. While NSW respectively prepares single submission of data and information, synchronizes data and information processing, and provides single decision-making for custom clearance and cargo clearance.

AMS was expected to operationalize NSW in 2008 (for six members) and 2012 (for less developed members-Cambodia, Laos, Myanmar, Vietnam). Currently, they still struggle domestically in integrating all government agencies (including ports and airports) under ASW platforms. There are also lengthy and complicated negotiations and capacity building efforts across government agencies and stakeholders. Some stakeholders even think that their jobs and positions are at stake if ASW is implemented, so the negotiations often reach a stalemate. These domestic struggles hinder ASW's implementation at the regional level. Some signs of progress in exchanging certificates of origin between Indonesia, Malaysia, Singapore, and Thailand have been made (Das 2017); while the rest of AMS is still struggling to organize their national system and link it to ASW. Based on this observation, ASEAN still has a long way to fully implement ASW, let alone formulating any common regulations in this area.

\section{Cybersecurity and Consumer Protection}

Table 3 below depicts that some AMS has no specific regulations on e-commerce sectors, let alone having harmonized regulations. Cambodia, for instance, has no regulation in place for almost every sector besides domain name. For cybercrime, all countries have enacted their domestic regulations, except for Cambodia and Lao. Regulation on privacy and consumer protection also received less attention by the members state, seeing how Brunei, Cambodia, Lao have not drafted the regulations on both issues, and Indonesia only partially did (Myanmar has regulated consumer protection). It has been mentioned a few times above that ASEAN consumers prefer brick-and-mortar shopping due to general distrust over online shopping platforms. Such distrust possibly stemmed from a lack of state protection towards consumers' privacy.

Table 3. Harmonization of Regulation in ASEAN by 2013

\begin{tabular}{l|l|l|l|l|l|l}
\multicolumn{1}{c}{$\begin{array}{c}\text { Member } \\
\text { Country }\end{array}$} & \multicolumn{1}{|c|}{$\begin{array}{c}\text { Trectronic } \\
\text { Transactions }\end{array}$} & \multicolumn{1}{|c|}{ Privacy } & \multicolumn{1}{|c|}{ Cybercrime } & $\begin{array}{c}\text { Consumer } \\
\text { Protection }\end{array}$ & $\begin{array}{c}\text { Content } \\
\text { Regulation }\end{array}$ & Domain Names \\
$\begin{array}{l}\text { Brunei } \\
\text { Darussalam }\end{array}$ & Enacted & None & Enacted & Partial & Enacted & Enacted \\
\hline Cambodia & Draft & None & Draft & None & Draft & Enacted \\
\hline Indonesia & Enacted & Partial & Enacted & Partial & Enacted & Enacted \\
\hline $\begin{array}{l}\text { Lao People's } \\
\text { Democratic } \\
\text { Republic }\end{array}$ & Enacted & None & None & Draft & Enacted & Partial \\
\hline Malaysia & Enacted & Enacted & Enacted & Enacted & Enacted & Enacted \\
\hline Myanmar & Enacted & None & Enacted & Enacted & Enacted & Enacted \\
\hline Philippines & Enacted & Enacted & Enacted & Enacted & None & Enacted \\
\hline Singapore & Enacted & Enacted & Enacted & Enacted & Enacted & Enacted \\
\hline Thailand & Enacted & Partial & Enacted & Enacted & Partial & Partial \\
\hline Viet Nam & Enacted & Partial & Enacted & Enacted & Enacted & Enacted \\
\hline
\end{tabular}

Source: UNCTAD-ASEAN (2013) 
Moreover, data from AT Kearney (2015) and CCCS (2017) reports show that 8 out of 10 countries carrying the most risk of cyber-attacks are located in Asia, including 4 AMS (Thailand, Indonesia, Philippines, and Malaysia). All of these factors contribute to the low level of consumers willingly using online payments, low rate of credit card penetration, and reluctance in sharing their financial information on the internet (CCCS 2017). ASEAN consumers preferred the COD method over e-payments, which could incur losses to the sellers if the consumers suddenly cancel the order.

Realizing these shortcomings, ASEAN prepared USD 10 million investment in cybersecurity to develop technical, policy, and strategic capabilities. However, progress has been painfully slow. Until very recently, ASEAN still grapples around the cybersecurity concept itself and considers it merely in the context of terrorism and online content (fake news), not e-commerce (Noor 2018). Only in 2018, when Singapore took the chairmanship of ASEAN, it pushed forward the urgency of the cybersecurity agenda, not only those related to e-commerce. It has started from initiating ASEAN Cyber Capacity Program 2 years before its chairmanship, the establishment of the ASEAN-Japan Cybersecurity Capacity Building Center in Bangkok, and a successful attempt of the regional declaration during the ASEAN Ministerial Conference on Cybersecurity (AMCC) in 2019. Singapore also established cooperation with third parties like the US, EU, and NATO in addressing cybersecurity-related issues and provided free training and capacity building to AMS.

Singapore's efforts are partly due to their realization that the other AMS have no capacity nor the adequate infrastructure to resolve cybersecurity-related issues fully. In addition, ASEAN's decision-making system, which requires consensus from all members, has slowed down its operational and integration process in almost all areas. Therefore, Singapore's efforts have successfully convinced AMS to reach a consensus to issue a declaration to support non-binding United Nations Group of Governmental Experts on Developments in the Field of Information and Telecommunications in the Context of International Security (UNGGE). This declaration is considered as a bold move from ASEAN because the UNGGE contains complex security issues on cybersecurity, and ASEAN usually has some disinclination in dealing with such issues (Noor 2018). Even though these attempts are mostly directed toward national security sectors, the benefits are expected to spill-over to e-commerce sectors, which face a data breach, identity theft, ransomware, DDos attacks, and phishing as the most common cyberattacks. What is left to see is how ASEAN shall follow-up this declaration to actual implementation.

\section{Case Study: Indonesia e-Commerce}

Indonesia has the largest population in ASEAN and one of the highest mobile penetrations, making it a potentially lucrative market for e-commerce. Similar to the characters of most ASEAN consumers, most Indonesian consumers use their mobile phones to shop online, shop through social media platforms, and do not trust online payment. However, CCCS predicted that the e-commerce growth of this country will jump from USD 12.2 billion to USD 53 billion in 2025, almost two times higher than other AMS (CCCS 2017). Indonesia is also the home of most of ASEAN's unicorns in the digital economy, namely Go-Jek, Traveloka, Tokopedia, and Bukalapak, which also attracted multi-billion investment in the region. 
Google and Temasek Report (Anandan et al. 2018) asserted that the market for online travel in Indonesia and Thailand is the most prospective in ASEAN with a 20\% growth rate. This growth is also enhanced by Traveloka expansion to other ASEAN regions like Thailand, Vietnam, and Singapore. Meanwhile, Go-Jek gained most market share in the Indonesian ride-hailing and food delivery sector, which has reached USD 3.7 billion and 1 billion, respectively. To put it simply, Indonesia is leading the digital trade in ASEAN, reaching approximately USD 12 billion in valuation.

The tremendous growth of Indonesian e-commerce can be credited to four factors (Australian Government 2018). First, cheap mobile phones contribute to the increasing number of smartphone penetration. Second, there are growing numbers of the middle class with their disposable income. Third, large flow of investment amounted to USD 2.5 billion has been invested in the Indonesian e-commerce platform by Alibaba, Tencent, and Shopee. Lastly, more choices of payments are made available and make it possible for the unbanked population to conduct online purchases.

Nonetheless, based on the CCCS report (2017), Indonesian consumers are the least likely consumers in ASEAN who will put their card detail online, use online-based payment, and trust online shopping more than offline stores. Moreover, $80 \%$ of consumers also admit they use the internet to compare prices between online and offline stores, not for the actual purchase. Recently, online payment platforms, like OVO or GO-Pay (from Go-Jek), have been increasingly used by consumers. However, the providers have not been able to solve data theft, fraud, or other security-related issues which caused consumer loss (Yuniarni 2019). In e-commerce, consumer security and protection are crucial to ensure its growth. Indonesia has enacted Law on Consumer Protection in 1999, which ensures legal protection of consumer rights and creates fair trade for both parties, but it was not formulated to regulate consumer protection in e-commerce (UNCTAD-ASEAN 2013; Juwenie et al. 2016). There are no full regulations on transaction security to ensure the protection of personal identities (for both sellers and buyers). There are many cases of fraud and data theft, which shall be elaborated below, that go unresolved because of this. In other words, the conduct of business in e-commerce has mostly been neglected by lawmakers.

The Indonesian government had enacted Law No. 11 of 2008 on Electronic Information and Transactions (ITE Law), which set out basic regulations on the use of the internet in general, including electronic transactions. However, it was widely criticized as rubber law because it also contains provisions on personal defamation, threats, and religious blasphemy that frequently evoked by some citizens or politicians to prosecute each other (for politicians or government officials, they prosecute citizens who voiced some critics about them) (SEEK 2018). This controversial regulation was then amended by Law No. 19 of 2016.

Under President Widodo's administration, the government pays more attention to e-commerce as one of the promising sectors in Indonesia to generate economic growth. The government released the 'Indonesia E-Commerce Map 2017 (Peta Jalan Sistem Perdagangan Nasional Berbasis Elektronik Tahun 2017-2019) under Presidential Decree No. 74/2017 which plans out government's vision, strategies, priorities, and future (and ongoing draft) regulations on e-commerce. The roadmap laid out at least eight aspects of e-commerce regulations within the government's priority, namely funding, taxation, consumer protection, education, and human resources, logistics, communication infrastructure, cybersecurity, and establishment of executor 
management (Majalah ICT 2016). After a-year evaluation, the government realized some plans are irrelevant to the current development and added four additional plans to regulate data protection, cross border transaction, digital goods and services, and strengthening local competitiveness (Setyowati 2019). It evidently shows that regulations cannot catch up with fast technological advancement.

Moreover, though some regulations have legally been put in place, its enforcement remains weak, particularly for the cases that are related to consumer protection. There are large numbers of data theft and fraud cases involving e-commerce and its digital payment system, yet most of it goes unreported. It was reported by Liputan6 that there are at least 6.9 million data is being stolen every day, and accumulatively there have been 14.6 million data stolen in Indonesia since 2013. Most of the data are stolen from social media (56.11\%). As Indonesian mostly shop from social media and spend time on social media more frequently than other platforms, this situation is concerning. Not only social media, Go-Jek as the most popular ride-hailing and food delivery service in Indonesia was also found to be vulnerable to data theft due to a bug inside its system (Linggasari 2016).

Furthermore, with regards to payment, $40 \%$ of Indonesian consumers have similar characters with other ASEAN consumers with their preference toward cash-on-delivery (COD) and followed by bank transfers (Singapore Post 2014). Credit card remains unpopular due to low penetration rate, but recently, Go-Pay by Gojek and e-wallet called OVO have gained consumers and popularity among consumers who were initially adverse of online payment. However, based on the author's observation on Go-Jek's official Twitter account (GOJEK 2019), there are many instances when consumers reported some fraud cases that their Go-Pay balance suddenly disappeared from the system, or was stolen by others. In most cases, Go-Jek only resolved it by paying back the lost money without prosecuting the culprits. Not only from the consumer side, but some e-commerce platforms also suffer from cybercrime from people pretending to be sellers and buyers in order to obtain money from their promotions, namely BukaLapak. It was reported that the perpetrators were indicted after they accumulated approximately USD 6,000 from the cashback promotion after pretending to be sellers and buyers and deceiving other consumers, as well (Jurnaliston 2018).

Meanwhile, with regards to the trade of e-commerce goods with other countries (particularly intra-ASEAN), the largest hurdle arguably comes from Indonesian custom. For ASW, Indonesia, as one of the founders of ASEAN, has started sharing some of the data about certificates on origins and integrated its ports and shipment points. Its progress is applaudable ahead of some countries in ASEAN. However, Indonesia covers a vast territory that mostly consists of waters, so the largest challenge is to integrate all ports points (currently there are around 100, but only connected less than 20) and build more sea infrastructure to support the logistics. Sea Toll, which was initiated under President Widodo administration, has proved to quicken the delivery of goods between ports, but there are still so many ports to be connected.

Moreover, there are still some remaining obstacles in terms of custom regulations and handlings in Indonesia. In her report for ISEAS, Das (2017) listed a comprehensive list of AMS's custom procedures, and Indonesia's position is almost similar to leastdeveloped AMS for some categories (Table 4 below). 
Table 4. Indonesia Custom Score and Indexes among ASEAN Countries

\begin{tabular}{|c|c|c|}
\hline $\begin{array}{l}\text { Categories } \\
\end{array}$ & Rank/Score & ASEAN/World Average \\
\hline Ease of doing business & $62^{\text {th }}$ & Out of 189 countries $/ 4^{\text {th }}$ among AMS \\
\hline Time to export & 17 days & $\begin{array}{l}\text { Higher than ASEAN average of } 16 \\
\text { days. }\end{array}$ \\
\hline Time to import & 26 days & $\begin{array}{l}\text { The longest time to import among } \\
\text { AMS, tied with Lao }\end{array}$ \\
\hline LPI Customs Rank & 2.8 & $\begin{array}{l}\text { The worst score is } 1 \text { and the best is } \\
\text { 5. Better than Cambodia (2.6), Lao } \\
\text { (2.4), Myanmar (1.9), and tied with } \\
\text { Vietnam (2.8) }\end{array}$ \\
\hline \multirow[t]{2}{*}{ Clearance time } & $\begin{array}{l}2 \text { days } \\
\text { (without } \\
\text { inspection) }\end{array}$ & \multirow[t]{2}{*}{$\begin{array}{l}\text { Longest physical inspection period in } \\
\text { AMS, tied with the Philippines. }\end{array}$} \\
\hline & $\begin{array}{l}5 \text { days } \\
\text { (physical } \\
\text { inspection) }\end{array}$ & \\
\hline $\begin{array}{l}\text { \% of inspection for import } \\
\text { shipments }\end{array}$ & $8 \%$ & ASEAN average: $24.8 \%$ \\
\hline $\begin{array}{l}\text { Multiple inspection (\% } \\
\text { of shipments physically } \\
\text { inspected) }\end{array}$ & $3 \%$ & $\begin{array}{l}3^{\text {rd }} \text { highest in ASEAN ( } 1^{\text {st }} \text { rank is } \\
\text { Vietnam with } 7 \%)\end{array}$ \\
\hline $\begin{array}{l}\text { Border Administration } \\
\text { Index }\end{array}$ & 4.4 & $\begin{array}{l}\text { Score } 1 \text { (worse)-7(best). Only better } \\
\text { than Cambodia (3.4), Lao (3.4), } \\
\text { Myanmar (3.3), Philippines (4.3), and } \\
\text { Vietnam (4.0) }\end{array}$ \\
\hline Custom service index & 0.75 & $\begin{array}{l}\text { Score o (worst)-1(best). One of the } \\
\text { best in ASEAN (after Singapore and } \\
\text { Thailand) }\end{array}$ \\
\hline Efficiency of clearance & 2.9 & $\begin{array}{l}\text { Score 1(worst)-5(best). More efficient } \\
\text { than Lao, Cambodia, Myanmar. }\end{array}$ \\
\hline $\begin{array}{l}\text { Irregular Payment in export } \\
\text { and import }\end{array}$ & 3.1 & $\begin{array}{l}\text { Score } 1 \text { (worse)-7 (best). Better } \\
\text { than Cambodia, Lao, Myanmar, } \\
\text { Philippines, and Vietnam }\end{array}$ \\
\hline $\begin{array}{l}\text { Time predictability of Import } \\
\text { procedures }\end{array}$ & 3.8 & $\begin{array}{l}\text { Score } 1 \text { (worse) }-7 \text { (best). Better than } \\
\text { Cambodia, Myanmar, Philippines, } \\
\text { and Vietnam. Tied with Thailand }\end{array}$ \\
\hline Custom Transparency Index & 0.53 & $\begin{array}{l}\text { Score o (worst)-1(best). Better than } \\
\text { Cambodia and Philippines - No data } \\
\text { for Lao and Myanmar }\end{array}$ \\
\hline
\end{tabular}

Based on the explanation above, we can conclude that Indonesia has tried to improve its custom procedures and also enacted some bills related to e-commerce. However, law enforcement to indict perpetrators for violating consumers' rights remains weak and slowly formulated. There are rooms for improvement; however, the government, consumers, and all stockholders might need to speed up their paces as technology advancements shall always go faster than any legal regulations and policies. 
Cybersecurity and Custom Regulations as Trade Barriers in ASEAN e-Commerce:

Case of Indonesian e-Commerce

\section{Conclusion}

Along with the Revolution Industry 4.o, international trade has come to a new era. Digitized goods and services go across national borders easily and frequently, not having to comply with the existing international trade regulations. In this era, ASEAN, with its large market of 622 million people and some unicorns, emerges as one of the most promising players in this area. In the next ten years, it is projected that ASEAN will reap hundred billion dollars from this sector alone.

However, along with these opportunities, some challenges are present, as well. ASEAN consumers are found to be fonder of traditional brick-and-mortar shopping and still reluctant to trust e-commerce merchants and put their private data online. In addition, most AMS (excluding Singapore and Malaysia) are notoriously known to have lengthy and complicated custom procedures which have been the source of complaints from corporations and businesspeople. This paper argued that weak regulations on two of the most important sectors (cybersecurity and custom regulations) could hinder the potential growth of e-commerce at the state and the regional level.

There are some conscious efforts from ASEAN to resolve these hurdles through ASW and some steps to strengthen its cybersecurity. ASW aims to shorten and quicken the custom procedures for intra-ASEAN trade; however, the progress among nations seems to be slow, and in Indonesia, it may not work well as the period of custom clearance and procedures has not shown significant improvement yet. For cybersecurity, Singaporeled ASEAN has taken some steps to tackle cybersecurity issues within their regions, including the launching of the ASEAN Cyber Capacity Program and a cybersecurity center to provide capacity building for all members.

In conclusion, some efforts have been made, and some plans are implemented. However, there are persisting problems in cybersecurity and custom procedures in the region and in Indonesia that need to be addressed sooner than later. If ASEAN and Indonesia still aim to be leading actors in e-commerce and generate their economic growth from it, they need to quicken their paces a little bit more.

\section{References}

\section{Book and Chapter in Books}

Gao, Henry S, 2018. "The regulation of digital trade in the TPP: New trade rules for the digital age". In Chaisse, J., Gao, H. and Lo, C.F. Paradigm shift in international economic law rule-making: TPP as a new model for trade agreements?. Research Collection School of Law. Singapore: Springer.

\section{Journal and Online Journal}

Das, Sanchita Basu, 2017. "ASEAN Single Window: Advancing Trade Facilitation for Regional Integration”, ISEAS-Yusof Ishak Institute Perspective, September, 2017 (72):1-10.

Juwenie, M. A., et al. 2016. "Consumer Protection in E-Commerce Transactions in Indonesia,” Journal of Law, Policy, and Globalization, 47. 
Wahyuni, N., 2018. "Consumer protection in Indonesia on selling buy transaction through E-commerce.” Journal of International Trade, Logistics and Law, 4(1): 1-8.

\section{Online Articles}

Ahmed, Usman and Aldonas, Grant, 2015. "Addressing Barriers to Digital Trade. E15Initiative." International Centre for Trade and Sustainable Development (ICTSD) and World Economic Forum. [online]. in http://e15initiative.org/ wp-content/uploads/2015/o9/E15-Digital-Ahmed-and-Aldonas-Final.pdf [accessed 6 April 2020].

ASEAN Secretariat, 2017. "ASEAN Community Progress Monitoring System (ACPMS) 2017" [online]. in https://www.aseanstats.org/wp-content/uploads/2017/o9/ ACPMS_2017.pdf [accessed 6 April 2020].

ASEAN, 2006. "Technical Guide of ASEAN Single Window and National Single Windows Implementation (ASW Technical Guide)" [online]. in https://cil. nus.edu.sg/wp-content/uploads/2019/02/2006-ASW-Prot-Annexes-1.pdf [accessed 6 April 2020].

ASEAN, 2010. "The ASEAN E-Commerce Database Project" [online]. in https:// www.asean.org/wp-content/uploads/images/2012/publications/ASEAN\%20 eCommerce\%20Database\%20Project.pdf [accessed 6 April 2020]

ASEAN, 2015. "ASEAN Single Window: Lowering the Costs of Trade through Faster Customs Clearance." [online]. in https://www.asean.org/storage/ images/2015/October/outreach-document/Edited\%20ASEAN\%20Single\%20 Window-2.pdf [accessed 6 April 2020]

ASEAN, n.d. "E-commerce." [online]. in https://asean.org/asean-economiccommunity/sectoral-bodies-under-the-purview-of-aem/e-commerce/ [accessed 6 April 2020].

Gnanasagaran, Angaindrankuma, 2018. "Delivering the ASEAN Single Window", The ASEAN Post, 28 January, [online]. in https://theaseanpost.com/article/ delivering-asean-single-window [accessed 6 April 2020].

Gnanasagaran, Angaindrankumar, 2018. "Can ASEAN stop the scourge of cybersecurity threats?”, The ASEAN Post, 4 May, [online]. in https://theaseanpost.com/ article/can-asean-stop-scourge-cybersecurity-threats [accessed 6 April 2020].

Heinl, Caitriona, 2019. "An ASEAN way of cybersecurity: Unpacking the proposed ASEAN-Singapore Cybersecurity Centre of Excellence", Asia and Pacific Policy Society, 15 January. [online]. in https://www.policyforum.net/an-asean-wayof-cybersecurity/ [accessed 6 April 2020].

Jurnaliston, Reza, 2018. "Begini Modus Penipuan Transaksi yang Rugikan Bukalapak Rp 70 Juta”, Kompas, 20 December [online]. in https://nasional.kompas.com/ read/2018/12/21/13473681/begini-modus-penipuan-transaksi-yang-rugikanbukalapak-rp-70-juta?page $=2$ [accessed 6 April 2020].

Majalah ICT, 2016. "Here it comes Indonesia E-commerce Road Map", Majalah ICT, Edition 50, Desember, [online]. in http://www.majalahict.com/wp-content/ uploads/woocommerce_uploads/2016/12/Majalah-ICT-English-No.5O-2016. 
Cybersecurity and Custom Regulations as Trade Barriers in ASEAN e-Commerce: Case of Indonesian e-Commerce

pdf [accessed 6 April 2020].

Noor, Elina, 2018. "ASEAN Takes a Bold Cybersecurity Step", The Diplomat, 4 October, [online]. in https://thediplomat.com/2018/10/asean-takes-a-boldcybersecurity-step/ [accessed 6 April 2020].

Setyowati, Desi, 2018. "Baru Setahun, Sebagian Peta Jalan E-Commerce Sudah Tak Relevan”, Katadata, 3 October, [online]. in https://katadata.co.id/ berita/2018/10/o3/baru-setahun-sebagian-peta-jalan-e-commerce-sudahtak-relevan [accessed 6 April 2020].

Varma, Suvir and Alex Boulton, 2018. "Southeast Asia Churns Out Billion-dollar Startups" [online]. in https://www.bain.com/insights/southeast-asia-churns-outbillion-dollar-start-ups-snap-chart/ [accessed 6 April 2020].

Wardhani, Agustin S, 2018. "4,5 Miliar Data Dicuri Selama 6 Bulan Pertama 2018”, Tekno Liputan6, 12 October, [online]. in https://www.liputan6.com/tekno/ $\mathrm{read} / 3665291 / 45$-miliar-data-dicuri-selama-6-bulan-pertama-2018 [accessed 6 April 2020].

World Economic Forum's Executive Opinion Survey, n.d. "World Development Indicators" World Bank, [online]. in https://databank.worldbank.org/source/ world-development-indicators/preview/on\# [accessed 6 April 2020].

Yuniarni, Sarah, 2019. "Ride-Hailing Giants Enjoy Solid Growth in Indonesia, but Face Fraud Challenge, Survey Finds", Jakarta Globe, 30 January, [online]. in https://jakartaglobe.id/context/ridehailing-giants-enjoy-solid-growth-inindonesia-but-face-fraud-challenge-survey-finds [accessed 6 April 2020].

\section{Others}

ADB \& UN ESCAP, 2018. Embracing the E-Commerce Revolution in Asia And the Pacific. Philippines: ADB Publication.

Anandan, R., et al. 2018. e-Conomy SEA 2018: Southeast Asia's Internet Economy Hits an Inflection Point. Google Temasek. [online] in www.thinkwithgoogle. com/intl/en-apac/tools-resources/research-studies/e-conomy-sea-2018southeast-asias-internet-economy-hits-inflection-point/ [accessed 6 April 2020].

ATKearney, 2015. Lifting the Barriers to E-Commerce in ASEAN. Korea: ATKearney.

ATKearney, 2015. The ASEAN Digital Revolution. Korea: ATKearney. [online]. in https://ecommerceiq.asia/wp-content/uploads/2016/05/ASEAN-DigitalRevolution-AT-Kearney.pdf [accessed 6 April 2020].

Australian Government, 2018. E-commerce in Indonesia: A guide for Australian business. Australia: Commonwealth of Australia.

Cassey Lee \& Sanchita Basu Das, 2017. "E-Commerce \& ASEAN Economic Integration." Presentation at Symposium on E-Commerce, ASEAN Economic Integration, and Competition Policy and Law, 8 March. Singapore: Yusof Ishak Institute.

Competition and Consumer Commission of Singapore (CCCS), 2017. Handbook on Competition \& E-Commerce in ASEAN. Singapore: CCCS. [online]. in www. cccs.gov.sg/resources/publications/other-publications/asean-ecommercehandbook [accessed 6 April 2020]. 
Gojek, 2019. 12 June. [online]. https://twitter.com/gojekindonesia?lang=en [accessed 6 April 2020].

OECD, 2012. Indonesia: Regulatory and Competition Issues in Ports, Rail, and Shipping. Jakarta: OECD. [online]. in https://www.academia.edu/36327315/ OECD_Reviews_of_Regulatory_Reform_INDONESIA_REGULATORY_ AND_COMPETITION_ISSUES_IN_PORTS_RAIL_AND_SHIPPING [accessed 6 April 2020].

Singapore Government, 2018. ASEAN Agreement on Electronic Commerce. Singapore: Government of Singapore. [online]. in https://www.mti.gov.sg/-/media/MTI/ COS-2018/Factsheets/ASEAN-Agreement-on-Ecommerce-MTI-COS-2018Factsheet---final.pdf [accessed 6 April 2020].

Singapore Post Limited, 2014. Indonesia's eCommerce Landscape 2014: Insights into One of Asia Pacific's Fastest Growing Markets. Singapore: Singapore Post. [online]. in https://www.singpost.com/sites/default/files/knowledge_centre_ files/2015/10/141215-white-paper-indonesia.pdf [accessed 6 April 2020].

UNCTAD-ASEAN, 2013. Review of e-commerce legislation harmonization in the Association of Southeast Asian Nations. Geneva and New York: UN Publication.

United Nations ESCAP, 2015. Implementation Case 2 for Single Window: Malaysia. [www.youtube.com/watch?v=40eqTZqo7Qc]. Malaysia: UN ESCAP.

Wei, Tan, and Annisa Pratamasari. "E-Commerce in ASEAN: Current State, Opportunities, and Challenges", in International Trade Policy Class, 31 May. Seoul: Korea University. 
Cybersecurity and Custom Regulations as Trade Barriers in ASEAN e-Commerce:

Case of Indonesian e-Commerce 